\title{
Competitiveness and technical efficiency: Determinants in the groundnut oil sector of India
}

\author{
A. Amarender Reddy *, Ma Cynthia S. Bantilan ${ }^{1}$ \\ Markets, Institutions and Policies, International Crop Research Institute for the Semi-Arid Tropics, ICRISAT, Patancheru 502 324, Andhra Pradesh, India
}

\section{A R T I C L E I N F O}

Article history:

Received 21 March 2010

Received in revised form 10 November 2011

Accepted 9 February 2012

\begin{abstract}
A B S T R A C T
India imports about half of its domestic consumption needs of edible oils. Groundnuts are a major source of edible oils in India. One of the central problems of groundnut production and processing is huge inefficiencies due to an uncertain production environment owing to rainfed cultivation, the low resource base of smallholder farmers and processors, and the low adoption rates of improved technology. This paper addresses critical issues that impair the groundnut sector's international competitiveness and efficiency. The paper uses primary data collected from Indian farmers and processors of groundnuts to measure efficiency, and it suggests policies for reducing yield gaps and increasing efficiency. Specific policies suggested from the study are (a) the harnessing of improved varieties with attributes like drought tolerance, high oil content, high productivity for large-scale seed multiplication and distribution by public and private agencies; (b) viable village seed banks and seed networks through cycles of post-rainy season seed multiplication to meet the seed requirements in the rainy season and vice versa; (c) adoption of low-cost technologies to increase profitability and reduce risk; (d) oilseed clusters to facilitate scale and scope economies in processing units; and (e) capital subsidies to accelerate technological upgrading to shed inefficiency in the processing sector. The expected gains in efficiency in the production and processing of oilseeds are expected to result in producer and consumer gains which would justify the proposed incentives for seeds and for technological upgrading in the processing sector.
\end{abstract}

(c) 2012 Elsevier Ltd. All rights reserved.

\section{Introduction}

Groundnuts are the major source of edible oils in India. In the mid 1990s, India was self-sufficient in the production of edible oils, but in the post-WTO period imports increased to about half of domestic consumption (Table 1). Low yield levels, coupled with the non-competitive oilseed processing sector, meant that Indian edible oils were not able to compete with cheap imports in an open economy. This means that the sector cannot afford to be inefficient if it is to survive. The growth rate of edible oil production (1.3\% per annum) is far lower than edible oil consumption (4.6\% per annum); consequently, imports have increased by $12.2 \%$ per annum since 1996 (Table 1). Still, per capita consumption levels of edible oils in India (at $13.3 \mathrm{~kg} /$ year for 2009-2010) are lower than global averages ( $24 \mathrm{~kg} /$ year). With current growth rates, demand for edible oils is expected to increase from $15.1 \mathrm{mt}$ (million tons) in TE 2010 to $21.2 \mathrm{mt}$ by 2015, with a consequent rise in imports from $7 \mathrm{mt}$ to about $11 \mathrm{mt}$. Historically, oilseed crops have been

* Corresponding author. Tel.: +91 40 30713071/3517 (Direct); fax: +91 40 $30713074 / 75$.

E-mail addresses: a.amarenderreddy@cgiar.org (A. Amarender Reddy), c.bantilan@cgiar.org (M.C.S. Bantilan).

1 Tel.: +91 40 30713071/3517 (Direct); fax: +91 40 30713074/75. neglected compared to food grain-like paddy and wheat-for food security reasons. Even though there were some earlier attempts to enhance the productivity of edible oils, such as the implementation of the Technology Mission on Oilseeds (TMOs) after 1986, these were by and large unsuccessful and the gains achieved were not sustained. This was due to the price decline in domestic and international markets for edible oils, which came with the opening of the sector in late 1990s. The low prices reduced profit margins in oilseed farming and processing. Some studies highlight the huge inefficiencies and yield gaps in edible oil production and processing (Bhatia et al., 2006; Reddy, 2009; Gulati, 2002). However, there has been little work on the sources of the inefficiency and noncompetitiveness in the sector.

This paper specifically addresses this critical research gap and systematically examines the factors that influence the drivers of efficiency in the oilseed and the edible oil sectors in India, and takes the groundnut (GN) sector for intensive study. It first examines the competitiveness and sources of inefficiency in GNs and GN oil in India. Then it focuses on farmers and processors in a major GN growing district, Anantapur in South India, to provide empirical evidence to support the following objectives: (i) assess the competitiveness of the edible oil complex, with special reference to groundnuts in the pre-TMO period (1970-1986), the TMO period (1987-1995), and the post-WTO period (1996-2010); (ii) assess 
Table 1

Edible oil availability in India (million tons).

\begin{tabular}{|c|c|c|c|c|c|c|}
\hline Period & $\begin{array}{l}\text { Oilseed Production } \\
(\mathrm{mt})\end{array}$ & $\begin{array}{l}\text { Edible oil production } \\
(\mathrm{mt})\end{array}$ & $\begin{array}{l}\text { Edible oil consumption } \\
(\mathrm{mt})\end{array}$ & $\begin{array}{l}\text { Oil imports } \\
(\mathrm{mt})\end{array}$ & $\begin{array}{l}\text { Cake production } \\
(\mathrm{mt})\end{array}$ & $\begin{array}{l}\text { Population } \\
\text { (million) }\end{array}$ \\
\hline \multicolumn{7}{|l|}{ Mean } \\
\hline TE 1986 & 12.2 & 3.7 & 4.9 & 1.2 & 10.4 & 744.4 \\
\hline TE 1995 & 21.0 & 6.4 & 6.6 & 0.2 & 18.0 & 896.9 \\
\hline TE 2010 & 27.5 & 7.9 & 15.1 & 7.2 & 23.2 & 1189.7 \\
\hline \multicolumn{7}{|l|}{ Annual compound growth rates (\%) } \\
\hline Pre-TMOs period (1970-1986) & 1.5 & 1.5 & 1.8 & 0.3 & 1.5 & 2.14 \\
\hline TMO period (1987-1995) & 7.4 & 7.4 & 2.8 & -32.5 & 7.4 & 2.04 \\
\hline Post-WTO period (1996-2010) & 1.7 & 1.3 & 4.6 & 12.2 & 1.6 & 1.87 \\
\hline
\end{tabular}

Source: FAOSTAT (2011).

technical allocative efficiency and the factors influencing technical efficiency in the production and processing of GN; and (iii) evaluate policy options for enhancing efficiency in both the production and processing of GN.

\section{Edible oil policy scenario}

India maintained low import tariffs to facilitate a sufficient quantity of imports of edible oils to bridge the gap between supply and demand, and to keep prices at affordable levels for consumers. Further, procurement of oilseeds at Minimum Support Price (MSP) is not effective, and prices of oilseeds have largely been left to market forces (Gulati, 2002). With the large-scale import of cheaper palm oil and soy oil (together contributing 52\% of domestic edible oil consumption), which directly compete with GN oil, farmers replaced areas under oilseeds including GNs with other, competing, crops. As a consequence of the scarcity of oilseeds for crushing, most of the processing units either closed down or operated at less than full capacity. Further, the groundnut production and processing sectors are exposed to an uncertain production environment owing to more than $70 \%$ of the GN area being rainfed, the low resource base of smallholder farmers and processors, and low adoption rates of improved technology. Adoption rate of improved varieties is very low. Inefficiencies in the processing industry are still high, as the sector has been reserved for small-scale units for over five decades. This resulted in the persistence of inefficiencies in both the oilseed production and the processing industry, despite the availability of some high-yielding and profitable technology for oilseed production and processing units (Reddy, 2009).

Review of technical efficiency in the context of the groundnut, edibleoil sector in India

This section reviews the literature on efficiency in both production and processing technologies in agriculture. Binam et al. (2004) estimated technical efficiency among smallholder farmers in Cameroon and found that the mean levels of technical efficiency are $77 \%$ and $75 \%$, respectively, for groundnut mono-crop, and maizegroundnut farming systems. This suggests the existence of substantial potential gains in output with available technology and resources. The efficiency differences are explained significantly by credit, soil fertility, social capital, distance of the plot from the access road, and extension services. (Snapp et al., 2003) concluded that the research and extension have failed to (1) develop technologies that take into account farmers' resource constraints and risks; and (2) improve farmers' capacity to adapt technologies to their own situations in semi-arid tropics, it advocated the approaches that teach farmers how to maximize returns from the use of smaller, more affordable inputs. Studies by Ruttan (2002), Gulati (2002) and Reddy (2009) advocated yield-enhancing biolog- ical technology in developing countries like India, through investments in general and technical education, the rural physical infrastructure, and the construction of appropriate research and technology-transfer institutions. Songqing et al. (2002) highlighted the importance of seed and extension services, and sustained investment in varietal improvement in oilseeds to maintain productivity gains from research. Dios-Palomares and Martínez-Paz (2011) highlighted the importance of production and marketing associations, and Rahman (2003) highlighted the importance of rural infrastructure in enhancing the efficiency of agricultural production, and opening up opportunities for technology diffusion, marketing, storage, and resource supplies in developing countries. Some studies (Gulati, 2002; Reddy, 2009) on edible oils in India estimated that capacity utilization in processing units is less than $50 \%$.

As noted previously, groundnuts are the major source of edible oils in India ( $22 \%$ of edible oil production) in addition to mustard, and soybeans. About $60 \%$ of GN production is crushed for oil, and the remaining $40 \%$ is used either for seed or is consumed directly (FAOSTAT, 2011). Traditionally, India has been a major exporter of both GNs ( $\$ 279$ million/annum) and GN cake (\$21 million/annum), and has been an occasional exporter of GN oil (\$17 million/annum) (Table 2). Noting the importance of GNs, this study focuses on the productivity and efficiency of the Indian GN sector. Even though average yields increased from $819 \mathrm{~kg}$ per ha to $1210 \mathrm{~kg}$ per ha over the last two decades, studies at ICRISAT show that existing yields can be increased by about two to three times with available technology (Bhatia et al., 2006). Furthermore, some studies (Gulati, 2002; Reddy, 2009) found a direct link between the GN production pattern and capacity utilization of the processing units. Groundnut production peaked during the TMO period $(7.8 \mathrm{mt})$, then slightly decreased in the post-WTO period $(7.3 \mathrm{mt})$. It is interesting to note that the export of all GN products (seed, oil, and cake) increased during the post-WTO period (Table 2), in spite of an overall increase in edible oil imports. Hence, targeting the GN sector for increasing efficiency and production will not only decrease the import of edible oils but also increase exports.

Table 2

Trends in area, production and net exports of groundnut products in India. Source: FAOSTAT (2011)

\begin{tabular}{llll}
\hline Indicator & Pre-TMOs & TMOs & Post-WTO \\
\hline GN area (million ha) & 7.1 & 7.9 & 6.0 \\
GN yield (kg/ha) & 819 & 992 & 1210 \\
GN production (mt) & 5.8 & 7.8 & 7.3 \\
Net exports (million US \$) & & & \\
Groundnuts & 18.0 & 52.9 & 279.0 \\
GN oil & -0.4 & -0.2 & 17.0 \\
GN cake & 33.9 & 51.1 & 21.0 \\
\hline
\end{tabular}




\section{Methodology}

\section{Measurement of competitiveness}

Competitiveness can be defined in several ways, ranging from the nominal protection concept to the comparative advantage concept. Popular measures of global competitiveness are: the Nominal Protection Coefficient (NPC) and the Revealed Comparative Advantage (RCA). NPC is the ratio of a domestic reference price to an international reference price at a particular destination. In this study we used Mumbai in India as the place of reference. NPC has been estimated based on the exportable hypotheses for GNs and GN cake, importable hypothesis for GN oil up to 2000 and based on the exportable hypothesis from 2001 to 2009 (as India emerged as net exporter of GN oil during 2001-2009). NPC less than 1 indicates higher competitiveness and more than 1 indicates lower competitiveness in international markets.

The RCA is defined as follows:

$R C A=\left(X_{i j} / X_{i t}\right) /\left(X_{n j} / X_{n t}\right)$

where $X_{i j}$ represents exports in country $i$ for the $j$ th commodity; $t$ is a set of commodities and $n$ is a set of countries. The RCA measures a country's exports of a commodity, relative to its total exports and to the corresponding export performance of a set of countries, in this case Asia. If RCA $>1$, then a comparative advantage exists for that country when compared to the group of countries used in the study. However, RCA suffers from the problem of asymmetry. The index is made symmetrical, following the methodology suggested by Dalum et al. (1998), and the revised index is called 'revealed symmetric comparative advantage (RSCA). Mathematically, it can be expressed by the equation $R S C A=(R C A-1) /(R C A+1)$. This measure ranges between -1 and +1 and is free from the problem of skewness. A country is said to have comparative advantage in its exports if the corresponding RSCA value is positive and vice versa.

\section{Frontier production function and efficiency estimation}

The Stochastic Frontier Production (SFP) function was proposed by Aigner et al. (1977) and is used into estimate technical efficiency. The technical efficiency of an individual unit is defined in terms of the ratio of the observed output to the corresponding frontier output, conditional on the level of inputs used by the farm. Technical inefficiency is therefore defined as the difference between the farm's level of production and the frontier level of output.

A number of studies on efficiency measurement (Wang et al., 1996) predicted efficiency indices regressed against a number of household characteristics in an attempt to explain the observed differences in efficiency among farms, using a two-stage procedure. Battese and Coelli (1995) extended the stochastic production frontier model by suggesting that the inefficiency effects can be expressed as function of explanatory variables, reflecting farm-specific characteristics. The advantage of Battese and Coelli (1995) model is that it allows estimates of the farm specific sources and the factors explaining efficiency differentials among farmers in a single procedure and it overcome some general criticism of two stage model. The present paper implemented this model by using frontier 4.1software (Coelli, 1996). The model specification may be expressed as

$Y_{i}=x_{i} \beta+\left(v_{i}-u_{i}\right) \quad i=1, \ldots, N$,

where $Y_{i}$ is the logarithm of the production of the $i$-th farm, $x_{i}$ is a $k \times 1$ vector of logarithm of input quantities of the $i$-th farm, $\beta$ is vector of unknown parameters, and $v_{i}$ are random variables that are assumed to be iid, $N\left(0, \sigma_{v}^{2}\right)$, and independent of the $u_{i}$, which are non-negative random variables that are assumed to account for technical inefficiency in production and are assumed to be independently distributed as truncations at zero of the $N\left(m_{i}, \sigma_{u}^{2}\right)$ distribution; where

$m_{i}=z_{i} \delta$

and $m_{i}=$ inefficiency of $i$ th farm, $z_{i}$ is a $q \times 1$ vector of variables which may influence the inefficiency of a farm; and $\delta$ is vector of parameters to be estimated.

We use the parameterization from Battese and Coelli (1995), replacing $\sigma_{v}^{2}$ and $\sigma_{u}^{2}$ with $\sigma^{2}=\sigma_{v}^{2}+\sigma_{u}^{2}$ and $\gamma=\sigma_{u}^{2} /\left(\sigma_{v}^{2}+\sigma_{u}^{2}\right)$. Parameter $\gamma$, must lie between 0 and 1 . One can test whether any form of the SFP function is required at all by testing the significance of the $\gamma$ parameter. If the null hypothesis, that $\gamma$ equals zero, is accepted, this would indicate that $\sigma_{u}^{2}$ is zero and hence that the $\mathrm{u}_{\mathrm{it}}$ term should be removed from the model, leaving a specification with parameters that can be consistently estimated using ordinary least squares.

\section{Efficiency predictions, allocative efficiency and marginal effects}

The measures of technical efficiency of individual farms relative to the production frontier are defined as

$\mathrm{EFF}_{i}=E\left(\exp \left(Y_{i}\right) \mid u_{i}, x_{i}\right) / E\left(\exp \left(Y_{i}\right) \mid u_{i}=0, x_{i}\right)$,

where $Y_{i}$ is the production of the $i$-th farm. In the case of a production frontier, $\mathrm{EFF}_{i}$ will take a value between 0 and 1 . The efficiency measures can be defined as exp $\left(-u_{i}\right)$, a log form dependent variable.

Allocative efficiency is related to combination of inputs with the lowest costs, and scale efficiency refers to the optimum level of output selection. The farm is allocatively inefficient if it operates off the minimum cost expansion path and can be expressed as the following equation i.e.

$\mathrm{MP}_{J} / \mathrm{MP}_{1}=P_{J} / P_{1} \operatorname{Exp}\left(w_{1 j}\right) \quad J=2,3, \ldots k$

where $\mathrm{MP}_{j}$ is the marginal product of the $j$ th input and $P_{j}$ is the price of the $j$ th input and $w_{i j}(J=2,3, \ldots k)$ represents allocative inefficiency, i.e., \% of underutilization (if $w_{1 j}$ is +ve) or \% of over utilization (if $w_{1 j}$ is -ve value) of respective input. Either of these increases total cost for a given output. The stochastic production function, defined in Eq. (1), is a linearized approximation of a Cobb-Douglas production function. ${ }^{2}$

The parameter estimates, $\left(\delta_{q}, q=1, \ldots, Q\right)$ in the inefficiency model, only indicate the direction of the effects of these variables on inefficiency. By differentiating mean inefficiency in the inefficiency model with respect to each of the inefficiency effects variables (evaluated at their mean values), we can calculate the quasi-elasticities for each inefficiency effects variable $\left(\mathrm{z}_{\mathrm{q}}\right)$ ${ }^{a s} \bar{C}_{i}=\left(d m / d z_{q}\right) *\left(\check{z}_{q} / m\right)$ where ' $m$ ' stands for the estimated mean inefficiency of our sample; $\check{z}_{q}$ is the mean value of the inefficiency effects variables in question (Wilson et al., 2001). Typically, the marginal effects for continuous variables are computed by estimating a small change in one variable, holding all other variables fixed at their means. The marginal effects for discrete variables are computed by calculating the change in the dependent variable, resulting from a change in the discrete variable from 0 to 1 , holding all other variables fixed at their means. We are interested in the marginal effects of adoption of high yielding varieties (HYVs) over nonadoption (or adoption of expellers over ghanis in case of processing units). An average farm (or firm) does not exist in this case. The marginal effects are thus not computed for the average farm (firm) but computed separately for HYV adopters and non-adopters

\footnotetext{
${ }^{2}$ For example, if $Y_{i}$ is the log of output and $x_{i}$ contains the logs of the input
} quantities, then the Cobb-Douglas production function is obtained. 
(expellers and ghanis) and the difference is taken as the marginal effect.

\section{Data and sampling method}

The study used FAOSTAT (2011) data on exports, imports and production trends of oilseeds and GN products to estimate the RSCA. The price at Mumbai and the unit transport cost data from the production center (in this case from Nandyal near Anantapur district to Mumbai) is taken from local regulated markets to calculate the NPC. The research station, on farm demonstration and district average productivity data needed to assess the yield gaps in GN production is collected from ICRISAT. Input-output data has been collected to assess the technological gaps between different types of processing firms operating in the villages. The study used the data from a field survey conducted in a south Indian district (Anantapur) for assessing the technical and allocative efficiency of groundnut farmers and processors. Anantapur is a major groundnut growing district in India with about $79 \%$ of total cropped area under GN and a large number of both traditional ghanis and expellers have been operational for decades, and thus this district is ideal for drawing conclusions about the edible oil sector in India.

A multi-stage sampling design was followed in the selection of mandals, ${ }^{3}$ villages and farmers from Anantapur district. The four mandals with the highest area under GN cultivation had been selected for the intensive survey, of which two mandals are agriculturally developed and the remaining two mandals are underdeveloped as defined by groundnut yield. In the second stage, four villages were selected at random from each mandal, after ranking the villages based on the area under GN cultivation. In the last stage, 20 farmers were selected at random from each village. Farmers were post-classified based on farm size groups. In addition, two processing units were selected from each village. If the processing units did not operate within the village, units were selected from the adjacent villages where the village GNs was taken for processing. When selecting processing units, for comparability, only expellers or ghanis which were in operation for at least 60 days/annum were included, as most of the ghanis are not in working condition. Hence, a total of 320 farmers and 29 processing firms (after discarding the data of three processing units due to incomplete data) were selected for the field survey. The selected mandals were Gutti, Darmavaram, Narpala and Rayadurgam. The data collected are from agricultural year 2007.

\section{Results}

\section{Policy instruments and competitiveness}

Countries should specialize in commodities in which they are competitive in the free-market setting. The estimates of the RSCA and the NPC for GN kernel, oil, and cake in the pre-TMO, TMO, and post-WTO periods are given in Table 3 . The NPC for oil is $>1$ showing non-competitiveness, but for cake it is $<1$, indicating competitiveness in all the periods. The NPC for GN kernel is $>1$ in the pre-TMO and the TMO periods, then it is $<1$ in the post-WTO period. Results from the RSCA also confirm India's comparative advantage in cake and, for most of the years, in GN kernel, but not in GN oil (RSCA is negative in all three periods). During the TMO period, India had almost achieved self-sufficiency in edible oils; however, this was at the cost of $71 \%$ higher domestic prices than world prices. During the post-WTO period-with the opening up of this sector through a reduction in import tariffs to almost zero levels

\footnotetext{
${ }^{3}$ Mandal is an intermediary administrative block comprising 50-60 villages within district.
}

Table 3

Competitiveness of GN products (1980-2009). Source: FAOSTAT (2011)

\begin{tabular}{|c|c|c|c|c|c|c|}
\hline \multirow[b]{2}{*}{ Period } & \multicolumn{3}{|c|}{$\begin{array}{l}\text { Revealed symmetric } \\
\text { comparative advantage (RSCA) }\end{array}$} & \multicolumn{3}{|c|}{$\begin{array}{l}\text { Nominal Protection Coefficient } \\
\text { (NPC) }\end{array}$} \\
\hline & GN kernel & GN oil & GN cake & GN kernel & GN oil & GN cake \\
\hline Pre-TMO & 0.27 & -1.00 & 0.84 & 1.02 & 1.66 & 0.80 \\
\hline TMO & -0.08 & -1.00 & 0.83 & 1.17 & 1.71 & 0.81 \\
\hline Post-WTO & 0.39 & -0.99 & 0.81 & 0.94 & 1.06 & 0.85 \\
\hline
\end{tabular}

over successive years-the NPC was reduced significantly and imports increased. To some extent higher protection (NPC) during the TMO period, helped in higher productivity growth, which is shaded away during post-WTO period.

\section{Yield gaps in groundnut production}

As GNs are export-competitive, the option of increasing the availability of GNs through increasing domestic production needs to be explored. Some studies on GNs (Reddy, 2009; Bhatia et al., 2006) show that most of the farmers are not able to adopt the recommended inputs and cultural practices due to high risk exposure. Under irrigated conditions, yield gap-I (the yield gap between experimental stations and on-farm demonstration) and yield gap-II (the yield gap between on-farm demonstration and average district yield) for GN in the Anantapur district are 199\% and 137\%, respectively (Table 4 ). The total yield gap is estimated as 336\%. Similar yield gaps exist in rainfed areas (Bhatia et al., 2006). If we bridge these yield gaps at least by a half, the profitability of the crop will be increased which helps to increase the growing area and the production of the crop.

On farmers' fields, fertilizer consumption is just $83.2 \mathrm{~kg}$ per ha with a higher proportion of nitrogen, whereas the recommended practice is $20 \mathrm{~kg} \mathrm{~N}, 40 \mathrm{~kg} \mathrm{P}_{2} \mathrm{O}_{5}$, and $40 \mathrm{~kg} \mathrm{~K} \mathrm{O}_{2}$ per ha. Some farmers purchased old subsidized varieties of seed from government agencies; these agencies are not distributing a sufficient quantity of newly released varieties with high yielding attributes. Most of the farmers are not using low-cost recommended practices like weeding, providing protective irrigation at critical stages, use of micronutrients like gypsum (200-250 kg per ha), seed treatment with rhizobium inoculation, fungicide, and zero till with the seed drill which will simultaneously reduce costs with increase in yield given the high-risk environment. Studies show that the use of mechanical threshers instead of manual threshing helps reduce labor cost and post-harvest losses, but it is not popular due to the unavailability of threshing machinery. Generally, farmers sow groundnut as a pure crop, even though intercropping with a groundnut plus pigeon pea row ratio of $11: 1$ is considered as the best risk-management strategy under rainfed conditions in the study area.

\section{Technical and allocative efficiency in GN production}

In keeping with other technical efficiency studies, we have considered productivity in $\mathrm{kg}$ per ha as an output variable, with seed

Table 4

Yield gap (kg/ha) analysis of irrigated GN cultivation (2007).

\begin{tabular}{llll}
\hline Item & Min & Max & Mean \\
\hline Research station (kg/ha) & 2080 & 4960 & 3620 \\
On-farm demonstration plot (kg/ha) & 960 & 3050 & 1970 \\
$\begin{array}{l}\text { District Average productivity (kg/ha) } \\
\text { Yield Gap-I (\%) (yield gap between research } \\
\quad \text { station to on-farm demonstration) }\end{array}$ & 560 & 1080 & 830 \\
$\begin{array}{l}\text { Yield Gap-II (\%) (yield gap between on-farm } \\
\quad \text { demonstration to district mean) }\end{array}$ & 71 & 177 & 199 \\
$\quad$ Total Yield Gap (I + II) (\%) & 271 & 359 & 336 \\
\hline
\end{tabular}

Note: Yield gaps are\% to district average yield. 
( $\mathrm{kg} / \mathrm{ha}$ ), fertilizer ( $\mathrm{kg} / \mathrm{ha}$ ), labor (man days/ha), irrigation (number of irrigators), machine labor (hours/ha), and other expenses (including depreciation and interest on working capital calculated at $12 \%$ per annum in Rs./ha) considered as inputs. The variables included in estimating the technical inefficiency effects are age (years), education (years of schooling) of head of household, and farm size (ha); three dummy variables, one each for the adoption of high-yielding varieties $(\mathrm{HYV}=1$; else $=0)$, soil type (red soil $=0$, else $=1$ ), and contact with an extension worker (contact $=1$; else $=0$ ) were included in the model.

We have estimated three specifications-the OLS model; the Cobb-Douglas (C-D) frontier model; and the translog frontier model with technical inefficiency effects with a truncated normal distribution-by using groundnut farm-level data. The robustness of the estimated models is indicated by the value of the likelihood function, and the C-D frontier model was selected for the oilseed farm-level data, as it has the largest value from the log-likelihood function, and the parameter estimates are consistent with theoretical expectations. The $\gamma$-parameter associated with the variances in the stochastic frontier is significantly different from 0 , and is estimated to be 0.78 ; this indicates that $78 \%$ of the variation in the total frontier of the production function among the sample farmers was due to differences in their efficiencies, which justifies the use of technical inefficiency effects (Table 5). The technical efficiencies have been calculated using Eqs. (1) and (2). The mean technical efficiency (MTE) of farms ranges from 0.57 to 0.79 for small and large farmers, respectively, with an overall MTE of 0.71 (Table 6). Further, rank correlation of farms based on technical efficiencies from the above three models are more than $90 \%$, which

Table 5

SFP function (B\&C, 1995) Results of GN production (2007). Source: Field Survey

\begin{tabular}{|c|c|c|c|}
\hline Item & B & Mean & $\begin{array}{l}\text { Allocative } \\
\text { inefficiency } \\
\text { (wi) }\end{array}$ \\
\hline \multicolumn{4}{|l|}{ Determinants of production frontier } \\
\hline Constant & $\begin{array}{l}-1.08^{*} \\
(-4.41)\end{array}$ & & \\
\hline Log (seed qty in kg/ha) & $0.29 *(6.19)$ & 168.0 & 0.45 \\
\hline Log (fertilizer kg/ha) & $0.14^{*}(14.25)$ & 83.2 & 1.00 \\
\hline $\log$ (man-day/ha) & $0.17^{*}(3.17)$ & 134.6 & -0.85 \\
\hline Log (machine labor in hours/ha) & $0.01^{*}(4.36)$ & 0.7 & 0.14 \\
\hline Log (number of irrigations/ha) & $0.04^{*}(4.99)$ & 0.2 & 1.50 \\
\hline Log (other expenses in Rs./ha) & $0.13^{*}(5.15)$ & 2970.7 & 0.00 \\
\hline \multicolumn{4}{|l|}{ Determinants of inefficiency } \\
\hline Constant & $0.70^{*}(8.84)$ & & $\begin{array}{l}\text { Quacy- } \\
\text { elasticity }\end{array}$ \\
\hline $\begin{array}{l}\text { Age of the head of household } \\
\text { (years) }\end{array}$ & $0.01(-0.75)$ & 38.6 & -0.15 \\
\hline $\begin{array}{l}\text { Education of the head of household } \\
\text { (years of schooling) }\end{array}$ & $0.01(0.28)$ & 6.5 & 0.02 \\
\hline Farm size (ha) & $\begin{array}{l}-0.07^{*} \\
(-8.42)\end{array}$ & 4.2 & -0.96 \\
\hline $\begin{array}{l}\text { Dummy variable for Adoption } \\
\text { of improved variety } \\
\text { (yes }=1, \text { no }=0)\end{array}$ & $\begin{array}{l}-0.17^{*} \\
(-5.23)\end{array}$ & 0.5 & -0.59 \\
\hline Soil type (red soil = 0 ; else $=1$ ) & $0.07^{*}(2.42)$ & 0.5 & 0.22 \\
\hline $\begin{array}{l}\text { Contact with extension agent } \\
\quad(\text { yes }=1 ; \text { no }=0)\end{array}$ & $-0.02(-0.75)$ & 0.4 & -0.07 \\
\hline Gamma & $0.78^{*}(10.59)$ & & \\
\hline Log likelihood function & 138.70 & & \\
\hline LR test of the one-sided error & $269.2^{*}$ & & \\
\hline Sample size & 320 & & \\
\hline Mean technical efficiency & 0.71 & & \\
\hline
\end{tabular}

Note: Dependent variable log (production in quintal/ha); ${ }^{*}$ indicates significant at $5 \%$ level, values in parenthesis are $t$-ratios; Allocative inefficiency: +ve values indicate underutilization and -ve values indicate overutilization of respective inputs.

The LR statistic is given by $k=2[\ln \{\mathrm{L}(\mathrm{HA})\}-\ln \{\mathrm{L}(\mathrm{H} 0)\}]$, where $\mathrm{L}(\mathrm{HA})$ and $\mathrm{L}(\mathrm{H} 0)$ are the values of the likelihood function under the alternative and null hypotheses. The value of $\mathrm{k}$ has a Chi-square distribution with the number of degrees of freedom equal to the number of restrictions imposed.
Table 6

Technical efficiencies of farms in GN production (2007).

\begin{tabular}{llllll}
\hline $\begin{array}{l}\text { Category } \\
\text { of farms }\end{array}$ & $\begin{array}{l}\text { Mean } \\
\text { efficiency }\end{array}$ & $\begin{array}{l}\text { Number } \\
\text { of farms }\end{array}$ & CV (\%) & Minimum & Maximum \\
\hline $\begin{array}{lllll}\text { Farm size } \\
\text { Small }\end{array}$ & 0.57 & 67 & 21.98 & 0.23 & 0.72 \\
Medium & 0.70 & 109 & 10.41 & 0.53 & 0.83 \\
Large & 0.79 & 141 & 15.91 & 0.60 & 0.98 \\
Improved seed & & & & & \\
Traditional variety & 0.63 & 167 & 18.24 & 0.23 & 0.95 \\
HYVs & 0.81 & 153 & 12.60 & 0.40 & 0.98 \\
Soil type & & & & & \\
Red loams & 0.77 & 169 & 17.00 & 0.26 & 0.98 \\
Other & 0.65 & 151 & 18.33 & 0.23 & 0.97 \\
Extension & & & & & \\
Contact & 0.79 & 137 & 16.55 & 0.36 & 0.98 \\
No contact & 0.65 & 183 & 17.47 & 0.23 & 0.97 \\
Total & 0.71 & 320 & 19.56 & 0.23 & 0.98 \\
\hline
\end{tabular}

indicates the robustness of the results. Estimates of allocative inefficiencies in the use of different input levels in GN production reveal that the critical inputs like irrigation, fertilizers, seed, and machine labor were underutilized to the extent of $150 \%, 100 \%$, $45 \%$, and $14 \%$ respectively, while human labor is over utilized to an extent of $85 \%$ at given production costs (Table 5 ). The imbalance in the use of inputs may be due to the rationing of the inputs at flat rates in local markets. As a result, the costs of the most critical inputs (credit, water, and fertilizer) are lower, but due to their short supply they are mostly used for competing crops like paddy and other commercial crops, which are given greater importance by farmers due to their stable returns and for food-security reasons (Reddy, 2009). It is interesting to note that farmers are operating at decreasing returns to scale, as the summation of the elasticities is just 0.78 , which also confirms the lack of adoption of improved technology.

Small farms are $22 \%$ less efficient than large farms (Table 6). Labor use per hectare on small farms is $7.8 \%$ more than on large farms. Conversely, in the use of all other inputs, such as irrigation and fertilizer, use per hectare is less on small farms than it is on large farms (Table A1). This indicates that the small farmers follow low-input, low-output agriculture due to their low resource base and the high-risk environment. Farm size and the adoption of HYVs are negatively influencing the level of technical inefficiency in GN production (Table 5), which is consistent with other studies (Battese and Coelli, 1995). A 1\% increase in farm size will reduce inefficiency by $0.96 \%$, while adoption of HYVs reduces inefficiency by 59\%. The inverse relationship between farm size and inefficiency can be explained, to some extent, by the resourcefulness of large farmers in adopting scientific methods and their risk bearing ability. Contrary to some studies (Tauer and Mishra, 2006), the age and education of the head of household are insignificant. This may be due to the operation of two conflicting forces: on the one hand the educated and the young are willing to adopt new technology. On the other hand, most of the educated and the young are not interested in working on farms. Aged persons are reluctant to adopt improved technology. Nonetheless, the results confirm Kalirajan and Shand (1985) who concluded that in the adoption of technology, the informal education (understanding technology) of farmers is more important than is their level of formal education.

\section{Technology gaps in GN processing}

GN processing mainly comprises two stages: seed crushing and solvent extraction. The highly heterogeneous structure of the oil- 
seed processing industry in India is presented in Table 7. The power-operated ghanis, with a mortar and a wooden pestle with a 50-60 kg per day capacity and with an oil extraction ratio of $37 \%$ are the most common in rural India. Most of the ghanis are manufactured locally and suffer from being obsolete in design, with high power consumption and a large working capital requirement. They leave a high level of $8-12 \%$ residue oil in the cakes. The number of ghanis is large (about 60 thousand to 70 thousand) but their contribution to oilseed processing is low in India.

Expellers (small to medium scale): Expellers use metal screws to expel oil from seeds. They are larger than the ghanis, and their oil-expelling capacity ranges from 5 to 10 tons per day (TPD); some small-scale expellers with a capacity of 1 TPD are also available. The average recovery of oil by expellers is about $2-3 \%$ higher than with the ghanis. The improved expellers have additional advantages-such as better quality oil and cake-and they fetch higher prices and are readily marketable, with low wear and tear of critical parts, and higher energy efficiency. Only 30\% of groundnut cake is currently subjected to solvent extraction for further recovery of oil (de-oiling). Cake produced as by-product from expellers rather than from ghanis is preferred for further processing for extracting remaining oil in the cake by solvent extraction industry. If India were able to process the remaining $70 \%$ of cake, an additional 0.5 million tons of oil could be produced annually from all oilseed cake sources put together.

The field survey indicates that about $60 \%$ of the ghanis are closed down, and the capacity utilization of the remaining units is just $20-40 \%$. In most cases they operate for only 2-4 months at the peak of the harvest season. However, expellers are working in a profitable business but are exposed to year-on-year fluctuations in production and price risks. Overall, $70 \%$ of edible oil comes from this unorganized sector in unpacked (loose) form, which caters to non-brand-conscious consumers who comprise about $84 \%$ of all edible-oil consumers.

Large-scale plants (solvent extractors, oil refiners, vanaspati plants): These are large plants with modern technology, and they recover a major portion of oil left in the oilseed cake coming from ghanis and expellers, and they also extract oil from low-yield oilbearing seeds (for example soybean, cottonseed, rice bran). Only about $30 \%$ of oil production comes from this sector. A few wellintegrated brand-focused companies (dominated by four or five companies) with an annual installed capacity spanning from 1000 to 5000 TPD dominate this sector. Their profit margins are higher, due to the monopolistic pricing power of the high-end brand-conscious urban consumers who comprise about $16 \%$ of total edible-oil consumers.

\section{Technical and Allocative efficiency in GN processing units}

Out of 29 processing units selected for the study, 10 were expellers and 19 were power-operated ghanis. In the oilseed processing sector, the output considered is net value added (Rs.) per annum (sale value of GN oil, plus GN cake, minus cost of GNs), while labor (man days/annum), electricity consumption (kwh/annum), depreciation (the replacement value of machinery divided by life expectancy of machinery in years), plus the rental value of land and buildings (Rs./annum) are taken as inputs. The technical inefficiency effects included are distance from the nearest markets $(\mathrm{km})$ and the size of the nearest market (1000 ton/year), age of the processing unit (years), and a dummy variable to indicate vertical or horizontal integration of the processing unit with retail marketing, or rice mill, or other grain mills, or stand alone. Average annual capacity of ghanis and expellers are $42,690 \mathrm{~kg}$ and $57,340 \mathrm{~kg}$ respectively (Table 8 ). The extraction ratio is higher in expellers (0.39) than in ghanis (0.37). Total operating cost is higher for expellers (Rs.123,935/annum) than for ghanis (Rs.120,136/annum). With higher turnover, the cost-benefit ratio is higher for expellers (1.79) than it is for ghanis (1.01). The margin over costs is higher for expellers (Rs.3.87 kg of GNs processed) than for ghanis (Rs.2.85/kg). The processing margins of the expellers are roughly $35 \%$ more than the margins of the ghanis. A lower margin in ghanis is due to high labor charges, low throughput in the peak season, and higher operating costs. This clearly indicates the superiority of expellers over ghanis in cost benefit and in operating performance. Net profit per annum is also higher for expellers (Rs.98,066/annum) than ghanis (Rs.1338/annum) (Table 8; Tables A2 and A3).

In the case of oil mills, due to the small number of observations (only 29), only the log-linear Cobb-Douglas functional form was estimated. The $\gamma$-parameter associated with the variances in the stochastic frontier is significantly different from 0 and is estimated to be 0.99 for frontier production functions for the processing units, which indicates that $99 \%$ of the variation in the total frontier of the production function among oilseed processing units was due to differences in their efficiencies. This justifies the use of technical inefficiency effects (Table 9). Besides the production inefficiency, considerable allocative inefficiency exists in GN processing. Labor and electricity are underutilized to the extent of $154 \%$ and $340 \%$ respectively. This reflects underutilization of capacity, as most of the units work for only about 2-4 months of the peak market arrivals of GNs a year due to the seasonality of GN production. However, some expellers run more than 4 months a year, as they store inventory of raw material (GNs) and use other oilseeds (sunflower etc.) as raw materials for long periods in the off-season, depending on the availability of working capital. There are scale economies in GN processing, as the sum of the elasticities is 1.26 (Table 9). Therefore, there is a possibility for improving efficiency by increasing capacity utilization (increasing working days/year) and consolidation. Shortages of raw materials can be addressed by increasing the area under the cultivation of GN, adoption of off-season GN varieties, or other oilseeds (sunflower) in the region by identifying

Table 7

Status of the edible oil industry (2007). Source: Solvent Extraction Association of India (2011).

\begin{tabular}{|c|c|c|c|c|c|}
\hline S. No. & Type of vegetable oil industry & No. of units & Annual capacity (million tons) & $\begin{array}{l}\text { Average capacity } \\
\text { utilization (\%) }\end{array}$ & $\begin{array}{l}\text { Average capacity } \\
\text { (TPD) }\end{array}$ \\
\hline 1 & Mechanical crushing firms & 150,000 & 42.9 (In terms of seeds) & $10-30$ & 0.95 \\
\hline 1a & Ghanis (include both country and power operated) & 130,000 & 3.9 & 10 & 0.1 \\
\hline $1 \mathrm{~b}$ & Expellers & 20,000 & 39.0 & 30 & 5.0 \\
\hline 2 & Solvent extraction firms & 779 & 41.9 (In terms of Oil-bearing Material) & 33 & 156.7 \\
\hline 3 & Total refineries & 937 & 12.3 (in terms of oil) & 37 & 19.6 \\
\hline $3 a$ & Refineries attached with vanaspati firms & 127 & 5.1 (in terms of oil) & 45 & 33.3 \\
\hline $3 b$ & Refineries attached with solvent firms & 225 & 3.7 (in terms of oil) & 29 & 20.0 \\
\hline $3 c$ & Independent refineries & 585 & 3.5 (in terms of oil) & 36 & 16.7 \\
\hline 4 & Vanaspati firms & 268 & $\begin{array}{l}5.8 \text { (in terms of Vanaspati, Bakery } \\
\text { Shortening \& Margarine) }\end{array}$ & 19 & 59.0 \\
\hline
\end{tabular}

Note: Annual capacity is measured with assumption of $24 \mathrm{~h} /$ day, 300 working days/ year. 
Table 8

Cost benefit analysis of processing firms (per/annum/firm)

\begin{tabular}{llll}
\hline Item & Expeller & Ghanis & All \\
\hline GN (kg/year) & 57,340 & 42,690 & 47,738 \\
Oil (kg/year) & 22,360 & 15,790 & 18,058 \\
Cake (kg/year) & 34,400 & 26,460 & 29,202 \\
GN price (Rs/kg) & 19 & 19 & 19 \\
Oil price((Rs.)/kg) & 44.8 & 44.8 & 44.8 \\
Cake price ((Rs.)/kg) & 9 & 8.5 & 8.7 \\
Labor (Man days) & 197 & 295 & 261.10 \\
Electricity (kwh/year) & 2585 & 2464 & 2505.55 \\
Depreciation ((Rs)/annum) & 81,459 & 63,592 & 69752.79 \\
Total cost ((Rs)/annum) & 123,935 & 120,136 & 121,446 \\
Oil sale ((Rs.)/annum) & $10,01,792$ & 707,541 & 809,007 \\
Cake sale ((Rs.)/annum) & 309,623 & 224,950 & 254,148 \\
GN cost ((Rs.)/annum) & $10,89,414$ & 811,017 & 907,016 \\
NVA ((Rs.)/annum) & 222,000 & 121,474 & 156,138 \\
Extraction ratio & 0.39 & 0.37 & 0.38 \\
Margin((Rs.)/kg) & 3.87 & 2.85 & 3.27 \\
Profit ((Rs.)/annum) & 98,066 & 1338 & 34,693 \\
B/C ratio & 1.79 & 1.01 & 1.29
\end{tabular}

Table 9

SFP function (B\&C, 1995) results of GN processing units (2007). Source: Field Survey.

\begin{tabular}{|c|c|c|c|}
\hline Item & $\mathrm{B}$ & Mean & $\begin{array}{l}\text { Allocative } \\
\text { inefficiency }\end{array}$ \\
\hline \multicolumn{4}{|l|}{ Determinants of production frontier } \\
\hline Constant & $3.31^{*}(5.81)$ & & \\
\hline Log (labor man-day's/annum) & $0.37^{*}(2.24)$ & 261.1 & 1.5 \\
\hline Log (electricity kwh/annum) & $0.75^{*}(1.92)$ & 2505.6 & 3.4 \\
\hline Log (depreciation Rs/annum) & $0.14(0.95)$ & 69752.8 & 0.0 \\
\hline \multicolumn{4}{|l|}{ Determinants of technical inefficiency } \\
\hline Constant & $0.16(0.23)$ & & $\begin{array}{l}\text { Quacy- } \\
\text { elasticity }\end{array}$ \\
\hline Type $($ ghanis $=1$; expellers $=0$ ) & $0.71^{*}(6.96)$ & 0.65 & 1.20 \\
\hline $\begin{array}{l}\text { Distance from nearest market } \\
(\mathrm{kms})\end{array}$ & $0.02(0.39)$ & 6.40 & 0.23 \\
\hline Market size (1000 tons/year) & $\begin{array}{l}-0.58^{*} \\
(-3.22)\end{array}$ & 0.59 & -0.58 \\
\hline $\begin{array}{l}\text { Dummy variable for integration } \\
\text { with other related activities } \\
\text { (yes }=1 ; \text { no }=0)\end{array}$ & $\begin{array}{l}-0.03 \\
(-0.24)\end{array}$ & 0.66 & -0.06 \\
\hline Age of units (years) & $\begin{array}{l}-0.02 \\
(-0.73)\end{array}$ & 6.76 & -0.28 \\
\hline Sigma-squared & $0.22 *(4.52)$ & & \\
\hline Gamma & $0.99 *(23.0)$ & & \\
\hline Log likelihood function & -15.96 & & \\
\hline LR test & 17.08 & & \\
\hline Sample size & 29 & & \\
\hline
\end{tabular}

Note: dependent variable Log (net value addition Rs/annum); *indicates significant at $5 \%$ level, Allocative inefficiency: +ve values indicate underutilization and -ve values indicate overutilization of respective inputs; values in parenthesis are $t$ ratios; output and inputs are in logged form.

oilseed growing clusters. The size and distance of groundnut markets were important factors in determining the efficiency of processing units (Tables 9 and 10). A 1\% increase in distance from the market increases inefficiency by $0.23 \%$. And a $1 \%$ increase in market size decreases inefficiency by $0.58 \%$, vertical or horizontal integration of the units decreases inefficiency by $6 \%$, and older units are more inefficient.

These figures indicate that there is a considerable scope to increase the efficiency of GN production and processing with the existing technology. There is evidence that units with less than 5 years of operation that are located near markets, and that are integrated, are more efficient than their counterparts are. About $50 \%$ of the units reported this type of integration. This indicates the existence of scope economies among integrated firms through the sharing of common resources among different uses. Overall, the study indicates that there is more opportunity to increase effi-
Table 10

Technical efficiencies of processing units (2007).

\begin{tabular}{|c|c|c|c|c|c|}
\hline Type & $\begin{array}{l}\text { Mean } \\
\text { efficiency }\end{array}$ & $\begin{array}{l}\text { Number } \\
\text { of units }\end{array}$ & $\mathrm{CV}(\%)$ & Minimum & Maximum \\
\hline Expellers & 0.63 & 10 & 46.5 & 0.14 & 1.00 \\
\hline Ghanis & 0.30 & 19 & 53.2 & 0.11 & 0.73 \\
\hline \multicolumn{6}{|c|}{ Integration } \\
\hline Yes & 0.45 & 19 & 60.7 & 0.14 & 1.00 \\
\hline No & 0.34 & 10 & 70.6 & 0.11 & 0.99 \\
\hline \multicolumn{6}{|c|}{ Distance From Market } \\
\hline$<5 \mathrm{Kms}$ & 0.54 & 9 & 46.2 & 0.28 & 0.99 \\
\hline$>5 \mathrm{Kms}$ & 0.35 & 20 & 71.8 & 0.11 & 1.00 \\
\hline \multicolumn{6}{|c|}{ Age of the unit } \\
\hline$<5$ years & 0.46 & 15 & 64.7 & 0.11 & 1.00 \\
\hline$>5$ years & 0.35 & 14 & 59.7 & 0.16 & 0.76 \\
\hline All & 0.41 & 29 & 63.9 & 0.11 & 1.00 \\
\hline
\end{tabular}

Table 11

Cost benefit analysis of new investment in setting up expeller.

\begin{tabular}{lll}
\hline Cost benefits of new investments & $\begin{array}{l}\text { Conversion of ghanis } \\
\text { to expellers }\end{array}$ & New expeller \\
\hline $\begin{array}{l}\text { Investment required (Rs) } \\
\text { Breakeven point (t) }\end{array}$ & 295,040 & 550,300 \\
$\begin{array}{c}\text { Break even period (years } \\
\text { with 0\% discount rate) }\end{array}$ & 172.5 & 321.8 \\
$\begin{array}{l}\text { Internal Rate of Return (IRR) } \\
\text { for 9 years of operation }\end{array}$ & $28.9 \%$ & 5.6 \\
$\begin{array}{c}\text { Net Present Value NPV (Rs) with } \\
\text { discount rate of 12\% per annum }\end{array}$ & 171,532 & $-56,379$ \\
\hline
\end{tabular}

ciency in the processing sector than in GN production. Gale (1998) suggests that small firms' lack of the financial capital necessary to adopt new technologies is a more important barrier to technology adoption than is any other reason in developing countries. The breakeven period for the new investment required to upgrade from ghanis to expellers is 3 years; for installing new expellers it is 56 years (Table 11). The Internal Rate of Returns (IRRs) is $28.9 \%$ in the former case and only $8.6 \%$ in the latter case (which is well below the bank interest rate of $12 \%$ ). Hence, conversion of ghanis to expellers with capital subsidies is an economically feasible option in the short run, given the low and uncertain supply of groundnuts throughout the year.

\section{Policy implications}

The competitiveness indicators show that groundnut and groundnut cake are competitive, but groundnut oil is not competitive during the post-WTO period. Withdrawal of protection given to oilseed sector during the post-WTO period resulted in low productivity growth and the failure of the yellow revolution mid-way. To harvest fruits of any R\&D efforts like TMOs, the sector needs protection and support over a reasonably long period, so that $R \& D$ efforts diffuse to a wide geographical area so that they are self-sustained, even after the withdrawal of protection. In GN production, non-adoption of new HYVs, less than optimal input use resulting in persistently higher levels of yield gaps (about 300\%) between the research station and the farmers' fields. Under uncertain rainfed conditions to bridge higher yield gaps, the research and extension system should focus on low-cost technology with incremental approaches that take into account local resources and profitability for wider adoption of recommended technology, instead of simply focusing on package for maximizing yield. The current level of efficiency can be improved by replacing the dominant old varieties with new improved varieties. 
The efficiency in groundnut processing is staggeringly low (only $41 \%$ ) compared to other industries in India (Majumdar, 1998). The mean efficiency of ghanis-traditional small-scale village-level units, which are numerically large in number in the edible oil industry-is $30 \%$, which is significantly lower than for expellers (63\%). The coexistence of inefficient ghanis along with the more efficient expellers in rural areas is due to the lack of short-run flexibility needed to convert ghanis into expellers, because of the relatively high adjustment costs which is beyond the financial capability of small-scale processors. The processors have to wait for 3.8 years to breakeven for the investment incurred from converting ghanis into expellers. The breakeven period for installing a new expeller is about 56 years. The IRR for installing a new expeller is below opportunity cost, resulting in no new investment in the expeller industry for a long period. Small-scale operators cannot wait for such a long breakeven period. Hence, to increase efficiency in the processing sector, small processors require capital subsidies upfront to finance the fixed costs in installing expellers. Factors like price risk, the need for large working capital to maintain inventory of raw material, under-capacity utilization particularly during the gestation period also hindering new investments in expellers. The government initiatives like TMOs mostly focused on production sector with little emphasis on processing sector needs to be corrected. The efficiency of groundnut processing units substantially increases with bulk market arrivals in the nearest markets, and growth in market size, one way to address the optimum market size is the development of oilseed clusters (with incentives for cultivation of all suitable oilseed crops like sunflower, mustard, soybean along with GNs), with the best transport and infrastructure facilities. This will reduce transaction costs for farmers and processors. This will also increase the yearlong availability of raw material in a sufficient quantity to run processing units at full capacity in the long run. The development of clusters will also facilitate contract farming and farmer-producer associations which will promote wider adoption and diffusion of the improved varieties with desirable quality traits like high-oil content that are preferred by the processing sector (Reddy, 2009). This also increases the scale and scope economies and the ability to scale up the revenue and profitability of the processing sector, and it reduces the breakeven time for installing expellers, and also attracts new investment to the sector.

The policy-action points that come from the study are first that there is a need for the replacement of old varieties like TMV-2 and JL-24 with new improved varieties like ICGS-11, ICGS-44, ICGV91114, and K-6 which have attributes such as high productivity, drought tolerance, and also high oil content. This can be done by providing sufficient incentives to both public and private seed producers and the distribution companies. The seed production and distribution requirements and the subsidy need to be considered for the seed varieties, or hybrids, in consultation with ICRISAT/ ICAR, keeping the yield potential and suitability prominent. Second, Seed Multiplication on farmers' fields, as well as both public and private seed companies to be encouraged in the post-rainy season to meet the seed requirements of the rainy season (and vice versa) to maintain viability and the germination percentage of the seeds. Third, there is a need to encourage oilseed production in clusters where incentives to be given to cultivate not only for GNs but also to all other suitable oilseed crops like mustard, soybean, sunflower; this would facilitate diffusion of newly released HYV (through seed networks) and would increase scale economies in small farm holdings and also increase scale and scope economies in processing units through increased availability of raw material to process in all seasons to run processing units with full capacity. Fourth, capital subsidies need to be given to encourage a switch from ghanis-which are numerically large but with low efficiency-to expellers-which are technologically and economically more efficient-to accelerate technological upgrading, and to shed inefficiency in the processing sector. This is in line with the broader national objective of decentralized rural industrialization and employment generation, instead of promotion of a few large-scale oilseed processing units with lower capacity utilization. The gains in efficiency in the production and processing of oilseeds will ultimately reduce the domestic prices of edible oils for consumers (Brennan and Bantilan, 2003), and will increase competitiveness and reduce the surge in large-scale imports of edible oils. This will justify non-market distorted seed subsidy to seed production and distribution companies and capital subsidy to processing units.

\section{Conclusion}

The significant contribution of this paper is its quantification of competitiveness and sources of inefficiencies in the groundnut edible-oil sector in the context of rising edible-oil imports and it suggests policy options to make the sector competitive. The study used primary data collected from farmers and processors of a predominant groundnut growing south Indian district. India's edibleoil sector is characterized by the coexistence of an internationally competitive oilseed and cake sector, with a non-competitive edible-oil sector. As a response to surging imports of edible oils, TMOs were introduced in 1986 and the results were visible in terms of the yellow revolution by 1995 , with almost negligible imports. However, liberalization policies introduced in the late 1990s diminished these gains, and India now imports more than half of its domestic edible-oil consumption. Keeping the competitiveness of production of GNs, the policy effort needs to focus on reducing huge yield gaps, which will shift the groundnut production frontier upward through the adoption of yield-enhancing low-cost technology like the adoption of improved seeds treated with rizobium and fungicide, micronutrients like gypsum, protective irrigation during stress times and use of mechanical threshers to save labor.

Unlike groundnut production, efficiency in groundnut processing is staggeringly low (only $41 \%$ ) compared to other industries in India (Majumdar, 1998). Additionally, the mean efficiency of ghanis, which are large in number in rural areas, is much lower (30\%) than of expellers (63\%). The high level of inefficiency is mainly due to the lack of flexibility needed to convert ghanis into expellers because of relatively higher adjustment costs. The processors have to wait for 3 years to reach the breakeven for the investment incurred from converting ghanis to expellers. The breakeven period for installing new expellers is about 5-6 years, resulting in no new investments in the expeller industry for a long time. Small-scale operators cannot wait for a long period to reach breakeven (Morrison, 1997). Hence, small processors require significant capital subsidies upfront to finance their fixed costs. Small processors also need sizeable working capital to maintain inventory of groundnuts needed to run the units after the peak market arrivals. The ongoing oilseed development programs and earlier TMOs largely concentrated on oilseed production, with little emphasis on the processing sector. This needs to be corrected. As the efficiency of groundnut processing units substantially increases with bulk market arrivals, and greater market size in the nearest market, one way to address efficiency is the promotion of oilseed clusters in identified potential areas based on agro-climatic suitability to incentivize cultivation of not only groundnut crop but also other oilseed crops like mustard, sunflower and soybean in clusters to supply sufficient quantity of oilseeds available for crushing to run processing units at full capacity. This will also help in the wider adoption and diffusion of improved varieties for the rainfed areas, and will facilitate contract farming and farmer-producer associations (Reddy, 2009).

Specific policies suggested from the study are (a) enhanced use of improved varieties with attributes like drought tolerance, high 
oil content, high productivity for large-scale seed multiplication and (or) distribution by both public and private agencies; (b) viable village seed banks and seed networks through cycles of the postrainy season, and seed multiplication to meet the seed requirements of the rainy season and vice versa; (c) adoption of low-cost technologies to increase profitability and reduce risk; (d) oilseed clusters to facilitate scale economies and capacity utilization in processing units; and (e) capital subsidies to accelerate technological upgrading to shed inefficiency in the processing sector. The expected gains in efficiency in the production and processing of oilseeds are expected to yield producer and consumer benefits which justify the proposal for a non-market, distorted, subsidy for both seed and technological upgrading in the processing sector.

\section{Acknowledgment}

The research study was carried out with the financial support of SANEI, Pakistan and Tropical Legumes-II project of ICRISAT.

\section{Appendix A. Supplementary material}

Supplementary data associated with this article can be found, in the online version, at doi:10.1016/j.foodpol.2012.02.004.

\section{References}

Aigner, D.J., Lovell, C.A.K., Schmidt, P., 1977. Formulation and estimation of stochastic frontier production function models. Journal of Econometrics 6 21-37.

Battese, G., Coelli, T., 1995. A model for technical efficiency effects in a stochastic frontier production function for panel data. Empirical Economics 20, 325-332.

Binam, J.N., Tonyè, J., Wandji, N., Nyambi, G., Akoa, M., 2004. Factors affecting the technical efficiency among smallholder farmers in the slash and burn agriculture zone of Cameroon. Food Policy 29 (5), 531-545.

Bhatia, V.S., Singh, P., Wani, S.P., Rao, K.A.V.R., Srinivas, K., 2006. Yield Gap Analysis of Soybean, Groundnut, Pigeonpea and Chickpea in India Using Simulation Modeling. Global Theme on Agroecosystems Report no. 31. Patancheru 502324 Andhra Pradesh, India: International Crops Research Institute for the Semi-Arid Tropics (ICRISAT). 156 pp.
Brennan John, P., Bantilan, M.C.S., 2003. Price and yield effects of spill-overs in international agricultural 'research: evidence from ICRISAT and Australia. Agricultural Economics 28 (203), 87-97.

Coelli, T., 1996. FRONTIER Version 4.1: A Computer Program for Stochastic Frontier Production and Cost Function Estimation. Department of Econometrics, University of New England, Armidale, NSW.

Dalum, B.K., Laursen, K., Villumsen, G., 1998. Structural change in OECD export specialization pattern: De-specialisation and 'stickiness'. International Review of Applied Economics 12, 447-467.

Dios-Palomares, R., Martínez-Paz, J.M., 2011. Technical, quality and environmental efficiency of the olive oil industry. Food Policy 36 (4), 526-534.

FAOSTAT, 2011. Food and agricultural organization statistics database (Faostat). <http://faostat.fao.org/>.

Gale, HF., 1998. Rural manufacturing on the crest of the wave: a count data analysis of technology use. American Journal of Agricultural Economics 80 (2), 347-359.

Gulati, A., 2002. Indian agriculture in a globalizing world. American Journal of Agricultural Economics 84 (3), 754-761.

Kalirajan, KP., Shand, RT., 1985. Types of education and agricultural productivity: a quantitative analysis of Tamil Nadu rice farming. Journal of Development Studies 21 (2), 232-243.

Tauer, Loren W., Mishra, Ashok K., 2006. Can the small dairy farm remains competitive in US agriculture? Food Policy (31), 458-468.

Majumdar, SK., 1998. Assessing comparative efficiency of the state-owned mixed and private sectors in Indian industry. Public Choice 96, 1-24.

Morrison, Catherine J., 1997. Structural change capital investment and productivity in the food processing industry. American Journal of Agricultural Economics 79 (1), 110-125.

Rahman, Sanzidur., 2003. Profit efficiency among Bangladeshi rice farmers. Food Policy 28, 487-503.

Reddy, AA., 2009. Policy options for edible oil complex. Economic and Political Weekly, 281-284.

Ruttan, VW., 2002. Productivity growth in world agriculture: sources and constraints. The Journal of Economic Perspectives 16 (4), 161-184.

Snapp, S.S., Blackie, M.J., Donovan, C., 2003. Realigning research and extension to focus on farmers' constraints and opportunities. Food Policy 28 (4), 349-363.

Solvent Extraction Association of India. 2011. http://www.seaofindia.com/accessed on 8th May 2011.

Songqing, Jin., Jikun, Huang., Ruifa, Hu., Scott, Rozelle., 2002. The creation and spread of technology and total factor productivity in China's agriculture. American Journal of Agricultural Economics 84 (4), 916-930.

Wang, J., Cramer, G.L., Wailes, E.J., 1996. Production efficiency of Chinese agriculture: evidence from rural household survey data. Agricultural Economics 15, 17-28.

Wilson, P., Hadley, D., Asby, C., 2001. The influence of management characteristics on the technical efficiency of wheat farmers in eastern England. Agricultural Economics 24, 329-338. 